\title{
ANALISIS LAPORAN AKUNTANBILITAS KINERJA INSTANSI PEMERINTAH PADA BADAN PENGELOLAAN PENDAPATAN DAERAH KABUPATEN CIANJUR
}

\author{
Indra Muhammad Syarief Hidayat ${ }^{1}$, Della Nurseptiani ${ }^{2}$, Faisal $^{3}$ \\ Fakultas Ekonomi dan Bisnis Islam Universitas Suryakancana Cianjur \\ ${ }^{1,2,3,4}$ Fakultas Ekonomi dan Bisnis Islam, Universitas Suryakancana \\ indraqilamsh@gmail.com,nurseptianidella@gmail.com, faesal200799@gmail.com \\ \begin{tabular}{l|l|l|} 
Masuk: Juli 2021 & Penerimaan: Agustus 2021 & Publikasi: September 2021 \\
\hline
\end{tabular}
}

\begin{abstract}
ABSTRAK
Penelitian ini dilakukan dengan latar belakang banyaknya kejadian korupsi, kolusi dan nepotisme yang semakin merajalela di lingkungan instansi pemerintahan, sehingga banyak realisasi pekerjaan yang tidak mencapai target yang telah ditentukan pada periode tertentu. Hal ini juga mengakibatkan banyaknya pihak yang menyoroti terhadap akuntabilitas pemerintahan. Tujuan dilakukannya penelitian ini adalah untuk mengetahui dan menganalisis Laporan Akuntabilitas Kinerja Instansi Pemerintah (LAKIP) yang disajikan apakah telah memenuhi fungsinya sebagai alat penatausahaan, pelaporan dan pertanggungjawaban serta sesuai dengan PERMENPAN \& RB Nomor 53 Tahun 2014 Tentang Petunjuk Teknis Perjanjian Kinerja, Pelaporan Kinerja dan Tata Cara Reviu Atas Laporan Kinerja Instansi Pemerintah. Metoda yang digunakan dalam penelitian ini adalah metode deskriptif dalam pemaparan dari setiap indikator yang didapat dari laporan Akuntabilitas Keuangan Instansi Pemerintah Kabupaten Cianjur. Adapun data yang digunakan oleh penulis adalah data kualitatif yang diperoleh dari website Badan Pengelolaan Pendapatan Daerah Kabupaten Cianjur. Hasil dari penelitian ini menunjukkan bahwa Laporan Akuntabilitas Kinerja Instansi Pemerintah yang disajikan oleh Badan Pengelolaan Pendapatan Daerah Kabupaten Cianjur bersifat informatif dan telah sesuai dengan yang diamanatkan oleh PERMENPAN \& RB Nomor 53 Tahun 2014.
\end{abstract}

Kata Kunci: Akuntabilitas, Penilaian Kinerja, BPPD

\begin{abstract}
This research was conducted against the background of the many incidents of corruption, collusion and nepotism that are increasingly rampant in government agencies, so that many work realizations do not reach the predetermined targets in a certain period. This has also resulted in many parties highlighting government accountability. The purpose of this research is to find out and analyze the Government Agency Performance Accountability Report (LAKIP) presented whether it has fulfilled its function as an administrative, reporting and accountability tool and is in accordance with PERMENPAN \& RB Number 53 of 2014 concerning Technical Guidelines for Performance Agreements, Performance Reporting and Governance How to Review Government Agency Performance Reports. The method used in this study is a descriptive method in the exposure of each indicator obtained from the Financial Accountability Report of the Cianjur Regency Government Agencies. The data used by the author is qualitative data obtained from the website of the Regional Revenue Management Agency of Cianjur Regency.
\end{abstract}

Copyright @ 2021, Aksyana: Jurnal Akuntansi dan Keuangan Islam Fakultas Ekonomi dan Bisnis Islam Universitas Suryakancana

Analisis Laporan Akuntanbilitas Kinerja Instansi Pemerintah Pada Badan Pengelolaan Pendapatan Daerah Kabupaten Cianjur 
The results of this study indicate that the Performance Accountability Reportof Government Agencies presented by the Regional Revenue Management Agency of Cianjur Regency is informative and has been in accordance with the mandate of PERMENPAN \& RB Number 53 of 2014.

Keywords: Accountability, Performance Asseesment, BPPD

\section{A. PENDAHULUAN}

Berkembangnya ilmu dan pengetahuan di bidang informatika dan sektor publik, membuat masyarakat menjadi memiliki peluang lebih banyak untuk bisa mengetahui aktivitas yang terjadi di lingkungan instansi pemerintahan. Rencana, kegiatan bahkan hingga realisasipun bisa dengan mudah di akses oleh masyarakat luas. Hal ini selaras dengan harapan dari semua lini yang menginginkan kegiatan yang berlangsung di pemerintahan menjadi efektif, efisien dan transparan. Banyak pihak yang saat ini menyoroti akuntabilitas pemerintahan, hal ini diakibatkan dari banyaknya kejadian korupsi, kolusi dan nepotisme yang semakin merajalela.

Adanya kebijakan otonomi daerah yang timbul tentu saja memberikan sisi positif dan negatif dalam pelaksanaannya. Sisi positifnya pemerintah memiliki kewenangan tersendiri untuk merencanakan, mengatur dan mengelola sendiri seluruh aktivitas yang ada di dalamnya, namun demikian hal itu tidak luput dari kekhawatiran adanya penyimpangan yang semakin besar dalam pelaksanaannya. Kebijakan untuk mengelola sendiri seluruh aktivitas di daerah menjadi tantangan yang besar yang harus diselesaikan oleh pemerintah daerah. Selain kompetensi dari sumber daya manusia yang harus terus ditingkatkan, tentunya pengendalian internal juga harus diperkuat untuk menghindari hadirnya oknum-oknum yang tidak bertanggung jawab dalam mengemban amanah untuk menjalankan fungsinya di pemerintah daerah.

Keleluasan kewenangan yang diberikan kepada pemerintah daerah dengan sendirinya menuntut adanya sinergi antara kinerja dan transparansi dalam pengelolaan keuangan. Sehingga upaya dalam mewujudkan prinsip-prinsip pemerintahan yang baik atau sering dikenal dengan istilah Good Governance, pada penyelenggaraan tugas-tugas institusi dan birokrasi yang dimiliki oleh pemerintah merupakan bagian tak terpisahkan dari reformasi birokrasi yang dicita-citakan. Sebagai tindak lanjut dari cita-cita pemerintah dalam mewujudkan pemerintahan 
yang baik (Good Governance), maka diwujudkan melalui adanya penyempurnaan dengan lahirnya Peraturan Menteri Pendayagunaan Aparatur Negara dan Reformasi Birokrasi Nomor 29 tahun 2010 tentang Pedoman Penyusunan Penerapan Kinerja dan Pelaporan. Sistem Akuntabilitas Kinerja Instansi Pemerintah (Sistem AKIP), sebagaimana dimaksud dalam Instruksi Presiden (Inpres) Nomor : 7 tahun 1999 dibangun dan dikembangkan dalam rangka perwujudan pertanggungjawaban pelaksanaan tugas pokok dan fungsi serta pengelolaan sumber daya pelaksana kebijakan dan program yang dipercayakan kepada setiap instansi pemerintah, berdasarkan suatu sistem akuntabilitas yang memadai. Dalam hal ini, pemerintah secara periodik wajib mengkomunikasikan pencapaian tujuan dan sasaran strategis organisasi kepada para stakeholders yang dituangkan melalui Laporan Akuntabiltas Kinerja Instansi Pemerintah (LAKIP).

Badan Pengelolaan Pendapatan Daerah Kabupaten Cianjur adalah salah satu unsur penunjang urusan pemerintahan bidang keuangan sebagaimana diatur dalam Peraturan Daerah Kabupaten Cianjur Nomor 8 Tahun 2016 Tentang Pembentukan dan Susunan Perangkat Daerah Kabupaten Cianjur yang dijabarkan dalam Peraturan Bupati Cianjur Nomor 79 Tahun 2016 Tentang Tugas dan Fungsi, Serta Tata Kerja Unit Organisasi di Lingkungan Badan Pengelolaan Pendapatan Daerah Kabupaten Cianjur.

Seperti yang telah disebutkan dalam Peraturan Bupati Nomor 79 tahun 2016 Bab II pasal 3 ayat (2) Bahwa Badan Pengelola Pendapatan Daerah mempunyai fungsi sebagai berikut:

1. Perumusan kebijakan Badan di bidang perencanaan, pelaksanaan, pembinaan, evaluasi dan laporan penyelenggaraan penunjang urusan pemerintahan daerah bidang keuangan;

2. Penyusunan kebijakan teknis bidang keuangan;

3. Pelaksanaan tugas dukungan teknis bidang keuangan;

4. Pemantauan, evaluasi, dan pelaporan pelaksanaan tugas dukungan teknis bidang keuangan;

5. pembinaan teknis penyelenggaraan fungsi-fungsi penunjang Urusan Pemerintahan Daerah bidang keuangan; 
6. Pelaksanaan fungsi lain yang diberikan oleh Bupati sesuai dengan tugas dan fungsinya.

Tujuan dari LAKIP sendiri yaitu untuk memberikan informasi terkait kinerja yang terukur kepada pemberi manfaat atas kinerja yang telah dicapai atau yang seharusnya tercapai, serta sebagai upaya untuk perbaikan berkesinambungan bagi instansi pemerintah untuk meningkatkan kinerjanya. Kemudian Isntansi Pemerintah yang wajib menyusup LAKIP sendiri yaitu Instansi Pemerintah Pusat yang terbagi menjadi tiga Entitas Akuntabilitas Kinerja, antara lain : Satuan Kerja, Unit Organisasi dan Kementrian/Lembaga. Sedangkan penyusun LAKIP setingkat Instansi Pemerintah Daerah adalah Entitas Akuntabilitas Kinerja SKPD atau sering dikenal dengan Kantor Dinas. Secara umum format/isi dari LAKIP secara singkat yaitu terdapat 4 isi utama, antara lain Uraian singkat organisasi, Rencana dan target kinerja yang ditetapkan, Pengukuran kinerja, dan yang terakhir adalah Penutup yang berisi evaluasi dan analisis kinerja untuk setiap sasaran strategis atau hasil program/kegiatan dan kondisi terakhir yang seharusnya terwujud.

Perumusan tujuan dan pemikiran tersebut memberikan gambaran yang cukup jelas bahwa Badan Pengelola Pendapatan Daerah mengemban tugas yang besar dalam Pemerintah Daerah agar tercipta penyelenggaraan pemerintah yang baik dan roda pemerintahan bisa berjalan sebagai mana mestinya dan bisa mencapai target kinerja yang baik.

\section{B. TINJAUAN TEORI}

\section{AKUNTANSI SEKTOR PUBLIK}

Bastian (2007:15) mendefinisikan akuntansi sektor publik sebagai mekanisme teknis dan analisis akuntansi yang diterapkan pada pengelolaan dana masyarakat di lembaga-lembaga tinggi negara dan departemendepartemen di bawahnya, pemerintah daerah, BUMN, BUMD, LSM dan yayasan sosial, maupun pada proyek-proyek kerjasama sektor publik dan swasta. Nordiawan (2006:35) menyatakan akuntansi sektor publik adalah proses pencatatan, pengklasifikasian, penganalisisan dan pelaporan transaksi keuangan dari suatu organisasi publik yang menyediakan informasi keuangan bagi para pemakai laporan keuangan yang berguna untuk pengambilan keputusan. 
Akuntansi untuk sektor publik memiliki karakteristik yang berbeda dengan akuntansi yang digunakan sektor swasta. Perbedaan utamanya terlihat dari lembaga atau instansi yang menggunakan kedua ilmu akuntansi tersebut. Akuntansi untuk sektor publik biasanya digunakan oleh lembaga pemerintah daerah dan pusat.

Mudahnya, karakteristik akuntansi sektor publik ini berfokus pada dua hal. Pertama, akuntansi untuk sektor publik berfokus pada sifat lembaga. Jadi, sifat akuntansi ini adalah khusus organisasi non profit yang tidak menghasilkan laba. Misalnya seperti lembaga pemerintahan. Kedua, akuntansi untuk sektor publik berfokus pada tujuan lembaga. Sesuai namanya, akuntansi untuk sektor publik hanya menyediakan informasi pelayanan pada publik. Pelayanan untuk publik ini dilakukan untuk meningkatkan kesejahteraan dari masyarakat.

Dalam pelaksanaannya, ada beberapa komponen yang dapat mempengaruhi kinerja lembaga sektor publik. Pertama, pengaruh dalam bidang ekonomi. Misalnya berupa tingkat inflasi, nilai tukar mata uang, infrastruktur, dan lainnya. Selanjutnya pengaruh dalam bidang politik. Misalnya seperti pemerintahan yang berkuasa, hubungan antar masing-masing lembaga, dan lainnya.

Tujuan akuntansi untuk sektor publik yang selanjutnya berhubungan dengan accountability. Jadi, akuntansi untuk sektor publik ini akan memberikan informasi penting yang dibutuhkan oleh manajer lembaga publik. Informasi ini nantinya digunakan manajer sebagai laporan pertanggungjawaban seluruh bidang di bawah kewenangannya.

Bukan hanya itu, informasi ini juga digunakan sebagai laporan pertanggungjawaban kepada publik atas kinerja yang dilakukan lembaga pemerintah. Jadi, publik dapat melihat transparansi tentang seperti apa penggunaan anggaran publik oleh lembaga pemerintah.

\section{KONSEP KINERJA}

Pengertian kinerja yaitu suatu hasil kerja yang dihasilkan oleh seorang karyawan diartikan untuk mencapai tujuan yang diharapkan. Kinerja didefinisikan juga sebagai hasil-hasil fungsi pekerjaan/kegiatan seseorang atau kelompok dalam suatu organisasi yang dipengaruhi oleh berbagai faktor untuk

Copyright @ 2021, Aksyana: Jurnal Akuntansi dan Keuangan Islam 
mencapai tujuan organisasi dalam periode waktu tertentu. Kinerja dapat juga didefinisikan sebagai penentuan secara periodik efektivitas operasional organisasi, bagian organisasi dan karyawannya berdasarkan sasaran, standar dan kriteria yang telah ditetapkan sebelumnya. Kinerja adalah hasil kerja secara kualitas dan kuantitas yang dapat dicapai oleh seorang pegawai dalam melaksanakan tugas sesuai dengan tanggung jawab yang diberikan kepadanya. Kinerja adalah penampilan hasil karya personil baik kuantitas maupun kualitas dalam suatu organisasi. Kinerja dapat merupakan penampilan individu maupun kerja kelompok personil. Kinerja dalam organisasi merupakan jawaban dari berhasil atau tidaknya tujuan organisasi yang telah ditetapkan (Srimindarti, 2006).

Tiga perangkat variabel yang mempengaruhi perilaku dan prestasikerja atau kinerja, yaitu:

a. Variabel Individual, terdiri dari: kemampuan dan keterampilan, mental dan fisik, latar belakang (keluarga, tingkat sosial), penggajian dan demografis (umur, asal-usul, jenis kelamin).

b. Variabel Organisasional, terdiri dari: sumber daya, kepemimpinan, imbalan, struktur desain pekerjaan.

c. Variabel Psikologis, terdiri dari: persepsi, sikap, kepribadian, belajar, motivasi.

Pengukuran kinerja organisasi sektor publik meliputi aspek-aspek, antara lain:

a. Kelompok masukan adalah segala sesuatu yang dibutuhkan agar pelaksanaan kegiatan dapat berjalan untuk menghasilkan keluaran.

b. Kelompok proses adalah ukuran kegiatan, baik dari segi kecepatan, ketepatan, maupun tingkat akurasi pelaksanaan kegiatan tersebut.

c. Kelompok keluaran adalah sesuatu yang diharapkan langsung dapat dicapai dari suatu kegiatan yang dapat berwujud maupun tidak berwujud.

d. Kelompok hasil adalah segala sesuatu yang mencerminkan berfungsinya keluaran kegiatan pada jangka menengah yang mempunyai efek langsung.

e. Kelompok manfaat adalah sesuatu yang terkait dengan tujuan akhir

Berikut merupakan beberapa faktor yang mempengaruhi kinerja dalam proses pencapaiannya. Faktor tersebut meliputi faktor yang berasal dari intern maunpun ekstern. Faktor internal yaitu faktor yang dihubungkan dengan sifat-sifat 
seseorang. Misalnya, kinerja seseorang baik disebabkan karena mempunyai kemampuan tinggi dan seseorang itu tipe pekerja keras, sedangkan seseorang mempunyai kinerja jelek disebabkan orang itu mempunyai kemampuan rendah dan orang tersebut tidak memiliki upaya-upaya untuk memperbaiki kemampuannya. Faktor eksternal yaitu faktor-faktor yang mempengaruhi kinerja seseorang yang berasal dari lingkungan. Seperti perilaku, sikap, dan tindakan-tindakan rekan kerja, bawahan atau pimpinan, fasilitas kerja, dan iklim organisasi. Faktor internal dan faktor eksternal ini merupakan jenis-jenis atribusi yang mempengaruhi kinerja seseorang.

Penilaian kinerja (performance appraisal) adalah suatu proses atau kegiatan yang dilakukan oleh perorangan atau kelompok dalam sebuah perusahaan untuk mengevaluasi dan mengomunikasikan bagaimana karyawan melakukan pekerjaan dengan cara membandingkan hasil pekerjaannya dengan seperangkat standar yang telah dibuat dalam suatu periode tertentu yang digunakan sebagai dasar pertimbangan suatu kegiatan.

Penilaian kinerja merupakan metode mengevaluasi dan menghargai kinerja yang paling umum digunakan. Penilaian kinerja dilakukan untuk memberi tahu karyawan apa yang diharapkan pengawas untuk membangun pemahaman yang lebih baik satu sama lain. Penilaian kinerja menitik beratkan pada penilaian sebagai suatu proses pengukuran sejauh mana kerja dari orang atau sekelompok orang dapat bermanfaat untuk mencapai tujuan yang ada.

Penilaian kinerja digunakan untuk memberitahukan pada karyawan sejauh mana kinerja mereka dan imbalan yang akan mereka dapatkan. Penilaian kinerja juga bertujuan untuk mengevaluasi dan memberikan umpan balik pada karyawan yang akan mengembangkan karyawan dan juga keefektifan organisasi. Menurut Mangkuprawira (2002), tujuan penilaian kinerja adalah sebagai berikut:

a. Perbaikan prestasi kerja. Umpan balik pelaksanaan kerja memungkinkan karyawan, manajer, dan departemen personalia dapat membetulkan kegiatankegiatan mereka untuk memperbaiki prestasi.

b. Penyesuaian-penyesuaian kompensasi. Evaluasi kinerja membantu para pengambil keputusan untuk menentukan kenaikan upah, pemberian bonus, dan bentuk kompensasi lainnya. 
c. Keputusan-keputusan penempatan. Promosi, transfer, dan demosi biasanya didasarkan pada kinerja masa lalu atau antisipasinya. Promosi sering merupakan bentuk penghargaan terhadap kinerja masa lalu.

d. Kebutuhan pelatihan dan pengembangan. Kinerja yang jelek mungkin menunjukan kebutuhan akan latihan demikian juga prestasi yang baik, mungkin mencerminkan potensi yang harus dikembangkan.

e. Perencanaan dan pengembangan karier. Umpan balik prestasi mengarahkan keputusan-keputusan karier yaitu tentang jalur karier tertentu yang harus diteliti.

f. Penyimpangan proses staffing. Kinerja yang baik atau jelek mencerminkan kekuatan atau kelemahan prosedur staffing departemen personalia.

g. Ketidakakuratan informasional. Potensi kerja yang jelek mungkin menunjukan kesalahan-kesalahan dalam informasi analisis jabatan, rencana-rencana sumber daya manusia atau komponen-komponen sistem informasi manajemen personalia.

h. Kesalahan-kesalahan dalam desain pekerjaan. Kinerja yang jelek mungkin merupakan suatu tanda kesalahan dalam desain pekerjaan. Penilaian prestasi membantu diagnosa kesalahan-kesalahan tersebut.

i. Kesempatan kerja yang adil. Penilaian kinerja secara akurat akan menjamin keputusan-keputusan penempatan internal diambil tanpa diskriminasi.

j. Tantangan-tantangan eksternal. Terkadang kinerja dipengaruhi oleh faktorfaktor diluar lingkungan kerja seperti keluarga, kesehatan, kondisi finansial atau masalah pribadi lainnya. Dengan penilaian prestasi kerja, departemen personalia mungkin dapat menawarkan bantuan.

\section{AKUNTABILITAS}

Akuntabilitas merupakan konsep yang komplek yang lebih sulit mewujudkannya dari pada memberantas korupsi. Akuntabilitas adalah keharusan lembaga-lembaga sektor publik untuk lebih menekan pada pertanggungjawaban horizontal (masyarakat) bukan hanya pertanggungjawaban vertikal (otoritas yang lebih tinggi).

Copyright ( 2 2021, Aksyana: Jurnal Akuntansi dan Keuangan Islam Fakultas Ekonomi dan Bisnis Islam Universitas Suryakancana 
Akuntabilitas adalah pertanggungjawaban dari seseorang atau sekelompok orang yang diberi amanat untuk menjalankan tugas tertentu kepada pihak pemberi amanat baik secara vertikal maupun secara horizontal.

\section{a. Tingkatan Akuntabilitas}

1) Tingkatan akuntabilitas menurut majalah Akuntansi:

2) Akuntabilitas Personal. Akuntabilitas berkaitan dengan diri sendiri.

3) Akuntabilitas Individu. Akuntabilitas yang berkaitan dengan suatu pelaksanaan.

4) Akuntabilitas Tim. Akuntabilitas yang dibagi dalam kerja kelompok atau tim.

5) Akuntabilitas Organisasi. Akuntabilitas Internal dan Eksternal didalam organisasi.

6) Akuntabilitas Stakeholders. Akuntabilitas yang terpisah antara stakeholders dan organisasi.

\section{b. Dimensi akuntabilitas}

Dimensi akuntabilitas ada 5, yaitu (Syahrudin Rasul, 2002:11): Akuntabilitas hukum dan kejujuran (accuntability for probity and legality) Akuntabilitas hukum terkait dengan dilakukannya kepatuhan terhadap hukum dan peraturan lain yang disyaratkan dalam organisasi, sedangkan akuntabilitas kejujuran terkait dengan penghindaran penyalahgunaan jabatan, korupsi dan kolusi. Akuntabilitas hukum menjamin ditegakkannya supremasi hukum, sedangkan akuntabilitas kejujuran menjamin adanya praktik organisasi yang sehat.

\section{c. Akuntabilitas manajerial}

Akuntabilitas manajerial yang dapat juga diartikan sebagai akuntabilitas kinerja (performance accountability) adalah pertanggungjawaban untuk melakukan pengelolaan organisasi secara efektif dan efisien.

\section{d. Akuntabilitas program}

Akuntabilitas program juga berarti bahwa programprogram organisasi hendaknya merupakan program yang bermutu dan mendukung strategi dalam pencapaian visi, misi dan tujuan organisasi. Lembaga publik harus mempertanggungjawabkan program yang telah dibuat sampai pada pelaksanaan program. 


\section{e. Akuntabilitas kebijakan}

Lembaga-lembaga publik hendaknya dapat mempertanggungjawabkan kebijakan yang telah ditetapkan dengan mempertimbangkan dampak dimasa depan. Dalam membuat kebijakan harus dipertimbangkan apa tujuan kebijakan tersebut, mengapa kebijakan itu dilakukan.

\section{f. Akuntabilitas financial}

Akuntabilitas ini merupakan pertanggungjawaban lembagalembaga publik untuk menggunakan dana publik (public money) secara ekonomis, efisien dan efektif, tidak ada pemborosan dan kebocoran dana, serta korupsi. Akuntabilitas financial ini sangat penting karena menjadi sorotan utama masyarakat. Akuntabilitas ini mengharuskan lembaga-lembaga publikuntuk membuat laporan keuangan untuk menggambarkan kinerja financial organisasi kepada pihak luar. Laporan Akuntabilitas dipublikasikan tahunan, laporan akuntabilitas termasuk program dan informasi keuangan, seperti laporan keuangan yang telah diaudit dan indikator kinerja yang merefleksikan kinerja dalam hubungannya dengan pencapaian tujuan utama organisasi.

\section{g. BPPD}

Badan Pengelolaan Pendapatan Daerah Kabupaten Cianjur adalah salah satu unsur penunjang urusan pemerintahan bidang keuangan sebagaimana diatur dalam Peraturan Daerah Kabupaten Cianjur Nomor 8 Tahun 2016 Tentang Pembentukan dan Susunan Perangkat Daerah Kabupaten Cianjur yang dijabarkan dalam Peraturan Bupati Cianjur Nomor 79 Tahun 2016 Tentang Tugas dan Fungsi, Serta Tata Kerja Unit Organisasi di Lingkungan Badan Pengelolaan Pendapatan Daerah Kabupaten Cianjur.

Berikut adalah fungsi dari Badan Pengelola Pendapatan Daerah

1) Penyusunan kebijakan teknis pengelolaan pendapatan daerah;

2) Pelaksanaan tugas dukungan teknis pengelolaan pendapatan daerah;

3) Pemantauan, evaluasi dan pelaporan pelaksanaan tugas dukungan teknis pengelolaan pendapatan daerah;

4) Pembinaan teknis penyelenggaraan fungsi-fungsi penunjang urusan pemerintahan daerah di bidang pengelolaan pendapatan daerah;

5) Pelaksanaan administrasi badan; dan

6) Pelaksanaan fungsi lain yang diberikan oleh Bupati sesuai bidang tugasnya. 


\section{METODE PENELITIAN}

Dalam penelitian ini penulis menggunakan metode deskriptif dalam pemaparan dari setiap indikator yang didapat dari laporan Akuntabilitas Keuangan Instansi Pemerintah Kabupaten Cianjur. Adapun data yang digunakan oleh penulis adalah data kualitatif yang diperoleh dari website Badan Pengelolaan Pendapatan Daerah Kabupaten Cianjur.

\section{HASIL DAN PEMBAHASAN}

\section{Program/ Rencana Kerja Tahun 2019}

Rencana Kinerja Tahun 2019 adalah sasaran dan atau target kinerja yang ingin dicapai pada tahun 2019. Rencana Kinerja Tahun 2019 Badan Pengelolaan Pendapatan Daerah Kabupaten Cianjur mencakup Sasaran, Program dan Kegiatan yang akan dilaksanakan pada tahun 2019 dengan mengacu kepada Rencana Kerja (Renja) yang tentunya tahapan-tahapan dalam mewujudkan target kinerja jangka menengah sebagaimana telah ditetapkan dalam Rencana Strategis (Renstra). Untuk melaksanakan kebijakan yang merupakan perwujudan dari Visi dan Misi Badan Pengelolaan Pendapatan Daerah Kabupaten Cianjur, maka ditetapkan Program dan Kegiatan Tahun 2019 sebagai berikut :

Program Pelayanan Administrasi Perkantoran dengan didukung 16 Kegiatan, yaitu:

a. Penyediaan Jasa Surat - menyurat;

b. Penyediaan Jasa Komunikasi, sumber daya air dan listrik;

c. Penyediaan Jasa Pemeliharaan dan Perijinan Kendaraan Dinas/ Operasional;

d. Penyediaan Jasa Kebersihan Kantor;

e. Penyediaan Alat tulis Kantor;

f. Penyediaan barang cetakan dan penggandaan;

g. Penyediaan komponen instalasi listrik/ penerangan bangunan kantor;

h. Penyediaan peralatan rumah tangga;

i. Penyediaan bahan bacaan dan peraturan Perundang - Undangan;

j. Penyediaan makanan dan minuman Kantor;

k. Rapat-rapat koordinasi dan konsultasi ke luar daerah;

1. Penyediaan Jasa Tenaga Pendukung Administrasi Perkantoran;

m. Rapat-rapat koordinasi dan konsultasi dalam daerah;

Copyright $\odot$ 2021, Aksyana: Jurnal Akuntansi dan Keuangan Islam
Fakultas Ekonomi dan Bisnis Islam Universitas Suryakancana
Analisis Laporan Akuntanbilitas Kinerja Instansi Pemerintah Pada Badan Pengelolaan Pendapatan Daerah
Kabupaten Cianjur


n. Penyediaan jasa pengamanan Kantor;

o. Penyediaan peralatan kebersihan Kantor;

p. Penyediaan Jasa Pengemudi.

Program Peningkatan Sarana dan Prasarana Aparatur, didukung 9 Kegiatan yaitu :

a. Pengadaan Kendaraan Dinas/Operasional;

b. Pengadaan Perlengkapan Gedung Kantor;

c. Pengadaan Mebeulair;

d. Pengadaan Komputer;

e. Pengadaan Alat - alat Kantor;

f. Pengadaan Alat-alat Studio dan Komunikasi;

g. Pemeliharaan Rutin/Berkala Gedung Kantor;

h. Pemeliharaan Rutin/ Berkala Kendaraan Dinas/ Operasional;

i. Pemeliharaan Rutin/ Berkala Alat-alat Kantor.

Program Peningkatan Disiplin Aparatur, di dukung 2 Kegiatan yaitu :

a. Pengadaan Pakaian Dinas Beserta kelengkapannya;

b. Pengadaan Pakaian Khusus hari-hari tertentu.

Program Peningkatan Kapasitas Sumber Daya Aparatur, didukung 1 Kegiatan yaitu:

Bimbingan Teknis Implementasi Peraturan PerundangUndangan.

Program Peningkatan Pengembangan Sistem Pelaporan Capaian Kinerja dan Keuangan, didukung 4 Kegiatan yaitu:

a. Penyusunan Laporan Capaian Kinerja dan Ikhtisar Realisasi Kinerja SKPD;

b. Penyusunan Pelaporan Keuangan Semesteran;

c. Penyusunan Pelaporan Prognosis Realisasi Anggaran;

d. Penyusunan Pelaporan Keuangan Akhir Tahun.

Program Perencanaan dan Penganggaran, didukung 2 Kegiatan yaitu :

a. Penyusunan RENJA dan RENSTRA SOPD;

b. Penyusunan RKA-DPA SOPD dan RKAP-DPPA SOPD.

Program Peningkatan Pendapatan Daerah dengan didukung 10 Kegiatan, yaitu :

a. Pendataan dan Penilaian PBB-P2;

b. Pengelolaan Data dan Pencetakan SPPT dan DHKP PBBP2;

c. Pendaftaran dan Verivikasi PBB-P2 dan BPHTB; 
d. Penertiban dan Penagihan Pajak Daerah;

e. Pengawasan Dan Pemeriksaan Pajak Daerah;

f. Penatausahaan Piutang Pajak Daerah;

g. Pendaftaran dan Pendataan Pajak Daerah;

h. Perhitungan, Penilaian dan Penetapan Pajak Daerah;

i. Penyelenggaraan Retribusi Daerah;

j. Pelayanan Pajak Jago Berbasis Teknologi Informasi dan Komunikasi;

\section{Capaian Kinerja Organisasi}

Evaluasi kinerja dimulai dengan pengukuran kinerja berdasarkan dokumen penetapan kinerja Badan Pengelolaan Pendapatan Daerah Kabupaten Cianjur Tahun 2019. Dokumen penetapan kinerja digunakan sebagai dasar pengukuran kinerja karena telah mempertimbangkan ketersediaan sumber daya yang dimiliki Badan Pengelolaan Pendapatan Daerah TahunN 2019, sehingga dapat menggambarkan kinerja Badan Pengelolaan Pendapatan Daerah secara realistis dihubungkan dengan anggaran yang tersedia.

Pengukuran kinerja kegiatan dilakukan dengan menggunakan indikator kinerja kegiatan. Pengukuran ini dilakukan dengan memanfaatkan data kinerja.

Data kinerja diperoleh melalui sistem pengumpulan data kinerja dari dua sumber yaitu:

a. Data internal yang berasal dari sistem informasi yang ada baik laporan kegiatan reguler yang ada seperti laporan harian, mingguan, bulanan, triwulanan dan laporan kegiatan lainnya;

b. Data eksternal digunakan sepanjang relevan dengan pencapaian kinerja Badan Pengelolaan Pendapatan Daerah Kabupaten Cianjur.

Beberapa jenis indikator kinerja yang digunakan dalam pelaksanaan pengukuran kinerja kegiatan Badan Pengelolaan Pendapatan Daerah Tahun 2019 yaitu:

a. Indikator masukan (input) adalah segala sesuatu yang dibutuhkan agar pelaksanaan kegiatan dapat berjalan untuk menghasilkan keluaran. Dalam tahun 2019 indikator input diprioritaskan pada penggunaan dana kegiatan yang dilakukan pengukuran kinerja dengan satuan rupiah; 
b. Indikator keluaran (Output) adalah sesuatu yang diharapkan langsung dicapai dari suatu kegiatan yang dapat berupa fisik dan atau non fisik. Indikator Output yang digunakan bervariasi mulai dari output jumlah barang/jasa, dari hasil pelayanan ataupun pelaksanaan tugas lainnya, dengan satuan kegiatan desa, buah, blok, paket, lembar, unit, rupiah dan sebagainya;

c. Indikator Hasil (Outcome) adalah segala sesuatu yang mencerminkan berfungsinya output kegiatan pada jangka menengah(efek langsung), indikator ini menggunakan angka mutlak rupiah;

d. Indikator Manfaat (Benefit) dan Dampak (Impact) yang berkaitan dengan kegiatan tahun anggaran 2019 tidak dilakukan pengukuran.

Pengukuran kinerja mencakup kinerja kegiatan yang merupakan tingkat pencapaian target dari masing-masing indikator kinerja kegiatan. Pengukuran kinerja dimaksud dilakukan dengan menggunakan formulir Pengukuran Kinerja Kegiatan (PKK). Pengukuran tingkat pencapaian sasaran didasarkan pada data hasil pengukuran kinerja kegiatan.Pengukuran kinerja dimaksud dilakukan dengan menggunakan formulir Pengukuran Pencapaian Sasaran (PPS) Akuntabilitas Keuangan

Tabel Pencapaian Kinerja

\begin{tabular}{|c|c|c|c|c|c|c|c|}
\hline \multirow[b]{2}{*}{ No } & \multirow[b]{2}{*}{$\begin{array}{l}\text { Indikator } \\
\text { Sasaran }\end{array}$} & \multirow[b]{2}{*}{$\begin{array}{c}\text { Capa } \\
\text { ian } \\
2017 \text { s/d } \\
2019\end{array}$} & \multicolumn{3}{|c|}{ Tahun 2019} & \multirow[b]{2}{*}{$\begin{array}{c}\text { Target } \\
\text { Akhir } \\
\text { Renstra } \\
(\mathbf{2 0 2 1})\end{array}$} & \multirow{2}{*}{$\begin{array}{c}\text { Capaian } \\
2017 \text { s/d } \\
2019 \\
\text { terhadap } \\
2021(\%)\end{array}$} \\
\hline & & & Target & Realisasi & $\begin{array}{c}\% \\
\text { Realisasi }\end{array}$ & & \\
\hline 1 & 2 & 3 & 4 & 5 & 6 & 7 & 8 \\
\hline 1 & $\begin{array}{l}\text { Jumlah } \\
\text { Pendapatan } \\
\text { Asli Daerah } \\
\text { dari Sektor } \\
\text { Pajak Daerah }\end{array}$ & $\begin{array}{l}565.280 .993 .676,0 \\
0\end{array}$ & 194.363.499.633,00 & 197.938.776.391,00 & 101,84 & 991.086.100.218,00 & $57,04 \%$ \\
\hline 2 & $\begin{array}{l}\text { Jumlah } \\
\text { pendapatan } \\
\text { Asli Daerah } \\
\text { dari Sektor } \\
\text { Retribusi } \\
\text { Daerah }\end{array}$ & $\begin{array}{l}\text { 83.618.525.996,0 } \\
\text { 0 }\end{array}$ & 41.188.066.061,00 & 34.468.350.983,00 & 83,69 & - & - \\
\hline
\end{tabular}

Sumber: LAKIP BPPD 2019

Copyright @ 2021, Aksyana: Jurnal Akuntansi dan Keuangan Islam Fakultas Ekonomi dan Bisnis Islam Universitas Suryakancana Analisis Laporan Akuntanbilitas Kinerja Instansi Pemerintah Pada Badan Pengelolaan Pendapatan Daerah Kabupaten Cianjur 
Dari tabel diatas dapat kita lihat bahwa pada poin Jumlah Pendapatan Asli Daerah dari Sektor pajak Daerah untuk tahun 2019 mencapai 197.938.776.391,00 dari target tahun 2019 sejumlah 194.363.499.633,00 dengan presentase realisasi sejumlah 101,84. Pada poin ini angka realisasi melebihi jumlah target yang artinya Pendapatan Asli Daerah dari Sektor Pajak Daerah sudah berjalan dengan baik. Selain itu dari poin Jumlah Pendapatan daerah dari sektor retribusi daerah mencapai angka 34.468.350.983,00 dari target tahun 2019 sebesar 41.188.066.061,00 dengan presentase pencapaian sebesar 83,69\%. Pada indikator ini angka realisasi masih dibawah angka target pada tahun 2019 hal ini disebabkan adanya kendala teknis di lapangan seperti di Dinas Perhu bungan Pelaksasnaan pemungutan retribusi parkir didaerah obyek wisata tidak dilaksanakan di gerbang kawasan wisata cibodas dan beralih ke zona parkir yang telah ditentukan. Akan tetapi kendaraan pengunjung tidak parkir pada zona parkir langsung parkir dimasing- masing kawasan (lipi, tngp dan area golf cibodas). Selain itu kendala yang terjadi seperti Retribusi kebersihan persampahan yang seharusnya dipungut oleh Dinas Lingkungan Hidup Kabupaten Cianjur pada kenyataannya banyak yang telah diambil alih pemungutannya oleh pihak Kelurahan, RW, RT, Karangtaruna dll, dan tidak melakukan penyetoran retribusi ke kas daerah. Masih banyak lagi kendala teknis yang terjadi dilapangan, yanng mengakibatkan PAD dari sektor retribusi daerah belum mencapai target yang diharapkan.

Selain itu dalam indikator sektor daerah targetnya belum disertakan ke dalam renstra jangka panjang, sehingga BPPD tidak mencantumkan target dan realisasi yang yang dicantumkan adalah realisasi dan target tahunan saja.

Laporan Akuntabilitas Kinerja Instansi Pemerintah yang disajikan oleh Badan pengelolaan Pendapatan Daerah Kabupaten Cianjur telah sesuai dengan yang diamanatkan dalam PERMENPAN \& RB Nomor 53 Tahun 2014 Tentang Petunjuk Teknis Perjanjian Kinerja, Pelaporan Kinerja dan Tata Cara Reviu Atas Laporan Kinerja Instansi Pemerintah. Berikut disampaikan kegunaan LAKIP BPPD di Kabupaten Cianjur:

a. Bahan evaluasi bagi pihak yang membutuhkan;

b. Dinas Pengelolaan Pendapatan Daerah dalam laporan yang disajikan telah berupaya dalam mendukung fungsi laporan itu sendiri dalam hal 
mendorong instansi pemerintah unt uk menyelenggarakan tugas pemerintahan dan pembangunan secara baik dan benar;

c. Penyempurnaan dokumen perencanaan periode yang akan datang;

d. Dinas Pengelolaan Pendapatan Daerah kabupaten Cianjur, sebagaimana dalam laporan yang disajikan telah ditetapkan penentuan Rencana Strategis (Renstra) dalam bentuk rencana pembangunan jangka pendek, jangka menengah maupun jangka panjang. Hal ini sangat baik dalam penyelenggaraan pemerintahan secara berkala dan terorganisir turut andil dalam menunjang penyelenggaraan pemerintahan yang baik;

e. Hasil evaluasi dan perbaikan-perbaikan yang diinginkan bisa didapat guna penyempurnaan pelaksanaan program dan kebijakan yang akan datang untuk mendukung visi dan misi pemerintah dalam memajukan Kabupaten Cianjur;

f. Penyempurnaan berbagai kebijakan yang diperlukan;

g. Penentuan kebijakan di masa mendatang sangat ditunjang oleh penyelenggaraan pemerintahan pada masa kini melalui pertanggungjawaban yang dilakukan Badan Pengelolaan Pendapatan

Daerah Kabupaten Cianjur sebagaimana diamanatkan oleh undang-undang.

\section{E. KESIMPULAN}

LAKIP Badan Pengelola Keuangan Daerah Kabupaten Cianjur telah sesuai dengan PERMENPAN \& RB Nomor 53 Tahun 2014 Tentang Petunjuk Teknis Perjanjian Kinerja, Pelaporan Kinerja dan Tata Cara Reviu Atas Laporan Kinerja Instansi Pemerintah.

\section{REFERENSI}

Bastian, Indra. 2007. Audit Sektor Publik. Erlangga. Jakarta.

Laporan Kinerja Instansi Pemerintah (LKJIP) Tahun 2018, Kecamatan Campaka Mangkuprawira, Shafry. 2002. Manajemen Sumber Daya Manusia. Ghalia Indonesia. Jakarta.

Nordiawan, Deddi. 2006. Akuntansi Sektor Publik. Salemba Empat. Jakarta.

PERMENPAN \& RB Nomor 53 Tahun 2014 Tentang Petunjuk Teknis Perjanjian Kinerja, Pelaporan Kinerja dan Tata Cara Reviu Atas Laporan Kinerja Instansi Pemerintah 
Indra Muhammad Syarief Hidayat, dkk

Aksyana: Jurnal Akuntansi dan Keuangan Islam

Vol. 01 No. 01 September 2021

Santoso, Susan. Analisis Laporan Akuntabilitas Kinerja Pada Dinas Kebudayaan dan Pariwisata Provinsi Sulawesi Utara. Jurnal EMBA Volume 1 Nomor 4 Desember 2013. ISSN 2303-1174. 